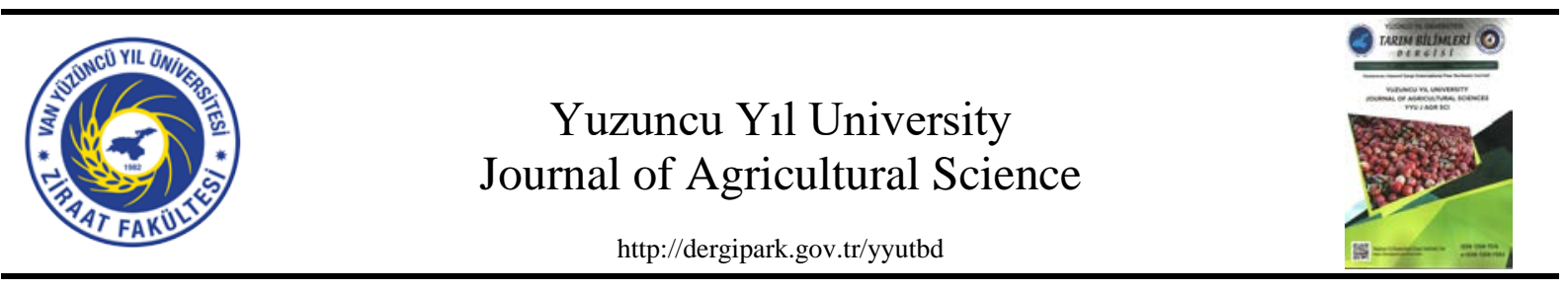

Review Article (Derleme)

Using DNA Barcoding in Fungal Taxonomy Younes REZAEE DANESH ${ }^{1 *}$, Semra DEMIIR ${ }^{2}$

${ }^{1}$ Soil, Fertilizer and Water Resources Central Research Institute, Ankara-Turkey

${ }^{2}$ Department of Plant Protection, Faculty of Agriculture, Van Yüzüncü Y1l Univerity, Turkey

${ }^{1}$ https://orcid.org/0000-0003-1060-0264 ${ }^{2}$ https://orcid.org/0000-0002-0177-7677

*Corresponding author e-mail: y.rdanesh@yahoo.com

\section{Article Info}

Received: 15.06.2020

Accepted: 05.11.2020

Online Published 31.12.2020

DOI: 10.29133/yyutbd.751901

\section{Keywords}

DNA Barcoding,

Fungi,

Molecular Taxonomy,

Species Concept.

\begin{abstract}
Totally, 1.5 million fungal species estimated, of which less than 10 percent have been described to date. Recent advances in molecular biology as well as gene sequencing technologies facilitate the discovery and identification of new species in various groups of living organisms, especially fungi. Morphological methods do not have efficiency for the identification of fungal species, so, using new techniques based on DNA data has been considered in the rapid and accurate fungal species identification. DNA Barcoding is a new technique with several years' backgrounds for detecting fungi and fungal like organisms. The Internal Transcribed Spacer in ribosomal RNA gene (ITSrDNA) has been considered as a suitable barcode sequence. The efficacy of this region's sequence data in most fungal groups has led to its use as a standard barcode by different mycologists. However, the ITS-rDNA region appears to be used as the primary barcode sequence for fungi of the genus or species group. The accurate species-specific identification is performed depending on the fungal group based on secondary barcodes. Due to the pleomorphic nature of fungi, the use of DNA barcoding is of importance. To date, hundreds of thousands of reference barcode sequences have been created for thousands of species of living organisms through DNA barcoding projects. The subsequent efforts of scientists are managing and automation of DNA barcoding in order to speed up the identification process.
\end{abstract}

\title{
Fungus Taksonomisinde DNA Barkodlamasının Kullanılması
}

\section{Makale Bilgileri}

Geliş: 15.06.2020

Kabul: 05.11.2020

Online Yayınlanma 31.12.2020

DOI: 10.29133/yyutbd.751901

\section{Anahtar kelimeler}

DNA Barkodlamas1, Funguslar,

Moleküler Taksonomi, Tür kavramı.
Öz: Günümüzde toplam 1.5 milyon olduğu tahmin edilen fungus türünün \%10'undan daha azı tanımlanmıştır. Moleküler biyolojideki son gelişmeler ve gen sıralama teknolojileri, çeşitli canlı organizma gruplarında, özellikle funguslarda yeni türlerin keşfedilmesini ve tanımlanmasını kolaylaştırmaktadır. Fungus türlerinin tanımlanmasında morfolojik yöntemler yeterli değildir, bu nedenle, hızlı ve doğru tanımlamada DNA verilerine dayalı yeni tekniklerin kullanılması ön plana çıkarılmıştır. DNA Barkodlama, fungus ve fungus benzeri mikroorganizmaları tespit etmek için kullanılan yıllık geçmişi olan yeni bir tekniktir. Ribozomal RNA genindeki ITS-rDNA uygun bir barkod dizisi olarak kabul edilmektedir. Bu bölge sekans verilerinin etkinliği, farklı mikologlar tarafindan birçok fungusta standart bir barkod olarak kullanılmasına yol açmıştır. Bununla birlikte, ITS-rDNA bölgesinin fungus cins ve türlerinin tanılanmasında birincil barkod dizisi olarak kullanıldığı görülmekte, fungus gruplarındaki türe özgü kesin tanılama ise ikincil barkodlara dayalı olarak yapılmaktadır. Fungusların pleomorfik doğası nedeniyle, DNA barkodlamasının kullanılması çok önemlidir. Bugüne kadar, DNA barkodlama projeleri ile 
binlerce canlı organizma türü için yüz binlerce referans barkod dizisi oluşturulmuştur. Bilim adamlarının bundan sonraki çalışmaları tanımlama sürecini hızlandırmak için DNA barkodunun yönetimi ve otomasyonu yönündedir.

\section{Introduction}

Species identification and classification is one of the most important parts of archeology and biological studies. Proper identification of species opens up useful information on any living organism, such as its ecological, physiological, biochemical, and social benefits and harms (Hebert et al., 2003; Crous et al., 2009). Taxonomy includes classification and nomenclature, and its purpose is to group living organisms into natural units, which makes it possible to describe biodiversity and species identification, and also reflect the kinship relations between different groups of living organisms (Crous et al., 2009). The goal of taxonomists is to create an acceptable order among the heterogeneous groups of living organisms to facilitate communication between the groups and to create methods that can be used and tested by others. To achieve this goal, scientists have used a variety of strategies, commonly referred to as species concepts. In scientific references, several kinds of species concepts with both theoretical and applied aspects (Taylor et al., 2000; Taylor, 2006). Applied concepts have identification and application values, including the concepts of morphological species, biological species as well as phylogenetic species. Although the phylogenetic concept of the species is also influenced by different variables such as the genome regions used to measure relationships between different fungal groups, but compared to other strategies are more reliable and repeatable, so in recent years it has become more popular among mycologists and is commonly used (Taylor et al., 2000; Taylor, 2006).

In the history of biology, scientists have used a variety of data to identify living organisms, including morphological, physiological, and biological data. The need for specialized knowledge is one of the main limiting factors in using morphological data to correctly and accurately identify fungal species. Some other special unique characters of fungi including special culture media, special storage conditions, limited growth rate, etc. are other problems of morphological methods. With recent advances in molecular biology and the development of DNA-based molecular methods, scientists have used these methods to quickly and accurately identify fungi. Molecular methods of fungal detection are mainly based on polymerase chain reaction (PCR) technique or other methods based on this reaction, which are commonly used in medical clinics, plant pathology laboratories, etc. to identify fungal species of high economic importance in medicine, agriculture and industry (Nancy and Binnicker, 2009). Other molecular methods include DNA hybridization, RFLP and AFLP techniques (Crous et al., 2009; Nancy and Binnicker, 2009). Due to the increasing of pathogenic fungal species in agriculture, nosocomial infections and the use of beneficial fungal species in industry, pharmaceuticals, biotechnology and related sciences and the discovery of cryptic species due to the lack of obvious morphological features, the importance of using more accurate and highly efficient methods in the separation of fungal species are obvious (Taylor et al., 2000; Crous et al., 2009). One of the new ways to identify the species is using DNA sequence information, which is very important in contemporary mycology. With recent advances in sequencing technologies, including pyrosequencing, gene sequencing is performed with high speed and accuracy. The use of sequence data in the identification of fungi is extremely important, especially for non-specialists in the field of identification based on the morphology of fungi. The idea of using a standard molecular identification system to identify species dates back to the 1990s (Hebert et al., 2003; Frézal and Leblois, 2008). During these years, the invention of the PCR method for regeneration of genes in living organisms, followed by the development of sequencing techniques from different parts of the genome and the possibility of comparing them, created a new horizon for solving problems facing taxonomists. By classifying the sequences and comparing them using statistical and bioinformatics methods, the phylogenetic tree is drawn and the kinship relationships of living organisms are determined. For this purpose, genomic DNA, mitochondria, chloroplasts, etc. are used. DNA barcoding is an identification system based on using of nucleotide sequence data, preferably a gene or a small number of gene region to quickly and accurately identify species of living organisms. Followed by identification of the 
phylogenetic position of a fungal species based on the nucleotide sequence data on the phylogenetic tree and the comparison of the target species sequence with other species with high similarity, it will be possible to design DNA barcoding for the species (Hebert et al., 2003). In fact, DNA barcoding identifies species using sequence data from one or more genes. It is not only a taxonomy system, but a highly efficient and accurate way to identify species in all divisions of all organisms. In fact, DNA barcoding is complementary to taxonomy, molecular phylogeny, and population genetics (Hebert et al., 2003; Frézal and Leblois, 2008; Crous et al., 2009; Costa and Carvalho, 2010, Das and Deb, 2015; Gosavi, 2016; Chaudhary and Dahal, 2017). This method is similar to molecular phylogeny in that sequence data are used to identify taxons, but the main goal in molecular phylogeny is to study and reconstruct kinship relationships between living organisms at different taxonomic levels (species, genus, family, order etc,). It is based on sequence data, and the more genes used, the more realistic the understanding of kinship relationships at different taxonomic levels obtained. Even with advances in sequencing technologies in recent years it is not unexpected the comparison of genomic sequences in phylogenetic studies. However, the main purpose of DNA barcoding is to securely identify taxons based on sequence data, and this data generally lacks phylogenetic efficiency at high taxonomic levels. In this review, considering to the strengths and weaknesses of common morphological and molecular methods for identification of fungi, it is tried to discuss on molecular techniques on fungal identification using the latest related articles from popular databases such as Google Scholar, Scopus, Medline, Pub med, Springer as well as Elsevier and using the suitable key words on fungal species identification, morphological species concept as well as DNA barcoding.

\section{From Traditional to Molecular Taxonomy}

Using of morphological features in the identification, taxonomy and phylogenetic relationships of living organisms has a history of more than 300 years, which is called morphological identification of species in scientific references. The basis of the morphology strategy is that morphological types or individuals can represent differences at the level of all species. The morphological concept of the species, has two major features. Firstly, the morphological traits among individuals of a species are fixed (homogenous) and, secondly, they show obvious differences between species. According to Taylor et al. (2006), the strength of the morphological concept of the species is its applicability to any fungal taxon and its extensive and long history of use (Termorshuizen and Arnolds, 1997; Taylor et al., 2000; Crous et al., 2009). Traditionally, phenotypic features, i.e. morphological and physiological properties, have been used to identification of fungi, but these characteristics, especially morphology, are strongly influenced by environmental conditions and are therefore highly variable (Raja et al., 2017). Differences in morphological features (preferably several features) are used to identify and describe species (Taylor et al., 2000; Crous et al., 2009). Another major limitation in the use of morphological traits for identification of most fungal groups is that the number of recognized characteristics is far less than the number of known species for each fungal species or the number of fungal species in a genus. Numerous examples of these limitations have been experienced by mycologists, including problems in identifying Fusarium species based on morphological data. Importantly, this fungus lacks sufficient morphological features to satisfactorily distinguish species, so some believe that the number of species in this genus is greater than the number of morphological features available to identify species (Termorshuizen and Arnolds, 1997). Occasionally, isolates belonging to the same species may show differences in some morphological features, such as colony size and color, shape and size of macro conidia, and chlamydospore formation.

With the introduction and use of molecular techniques, the taxonomy of Fusarium species has become a controversial issue. In particular, the integration of the phylogenetic species concept with DNA data has led to the description of new species, which includes a number of Sibling species. Identification of these species based on morphological characteristics is impossible (Termorshuizen and Arnolds, 1997; Taylor et al., 2000; Hebert et al., 2003). For example, 15 phylogenetic species have been identified within the Fusarium graminearum complex species, and it is not possible to distinguish between these species based on morphological data (Arver et al., 2011). The ineffectiveness of morphological traits in the successful separation of fungal groups in black yeast like fungi has also been experienced. The term black yeast is commonly used to describe melanin pigment- 
producing fungi that have both mycelial and yeast phases in the culture medium (Arver et al., 2011) and are considered pathogens of humans and other living organisms, especially in the brain and other organs. In people with weakened immune systems, it can sometimes be fatal (Termorshuizen and Arnolds, 1997; Taylor et al., 2000; Hebert et al., 2003). These fungi are also involved in the destruction of ornamental stones (Gadd, 2008) and antiquities. On the other hand, the positive roles of black yeast in environmental bioremediation as well as biodegradation of oil pollutants have been proven (Badali et al., 2011).

It was observed that that the genus Ramichloridium, whose boundaries are determined by morphological characteristics, includes a heterogeneous group of fungi. The researchers found that human pathogenic species classified earlier in the genus Ramichloridium belong to the genus Rhinocladiella in the order Chaeothyrilaes, while the genus Ramichloridium belongs to the order Capnodilaes (Badali et al., 2010). In the case of other fungal groups belonging to black yeasts such as Cladophialophora and Exophiala, it is not possible to identify the species only by relying on morphological traits (Badali et al., 2008; 2009; 2010). Problems in morphology-based identification led mycologists to using molecular methods. By introducing the polymerase chain reaction, it was possible to replicate gene regions from DNA samples. Therefore, by extracting DNA from fungal cultures, it was possible to reproduce parts of the genome for diagnostic purposes (Crous et al., 2009; Nancy and Binnicker, 2009). Subsequently, several polymerase chain reaction techniques were widely used, and even in some cases the detection and quantification of fungal species directly from infected samples (plant, blood, air, soil etc. ...) became possible (Nancy and Binnicker, 2009). By using Taq Man Real Time Assay technology, identification and quantification of Mycosphaerella species involved in the combined disease of banana Sigatoga carried out directly from infected samples of plants. Molecular approaches have higher speed, accuracy of operation and sensitivity compared to traditional methods, and in these methods, there are less health risks for researchers and personnel working with contaminated samples (Nancy and Binnicker, 2009). At present, nucleotide sequence data are commonly used in the identification of fungi in the medical sciences, agriculture, and industry. Nucleotide sequence data are also used to study the kinship relationships between living organisms at the preferred taxonomic levels in evolutionary biology (Nancy and Binnicker, 2009; Arver et al., 2011). With recent advances in sequencing technologies with high speed and accuracy of operation and significantly reduced the cost of sequencing, determining the sequence of genes or genomes of living organisms has become increasingly rapid. In this regard, fungi are among the leading groups and the complete sequence of the genome of a large number of fungal pathogens of human and plants as well as industrial fungi is available (Xu et al., 2006; Desjardins et al., 2011; Andersen et al., 2011). Pyrosequencing approach is a new technology that, unlike the chain-based approach, is a Real-Time sequencing method and uses the release of light as a sign for attaching a nucleotide to the target DNA strand. In this method, which was introduced in 1996, the addition of complementary nucleotide in the synthesized DNA chain leads to releasing of light based on a series of enzymatic interactions (Elahi and Ronaghi, 2004). With the accumulation of nucleotide sequence data, new ideas for the identification of living organisms have been formed or are being formed, and the ultimate goal of scientists is to create the technology needed to quickly identification species of living organisms with high reliability and automation. Hebert et al. (2003) first proposed an interesting and new way to identification animals based on cytochrome oxidase genes. They selected the 648-bp region of this gene for lack of introns, less recombination, and the haploid form of gene inheritance, which was acceptable in 95\% of cases. In fact, DNA barcoding was first developed to quickly and accurately identification of animal species in which the mouse mitochondrial genome was used as a reference, and its purpose today is to identification all eukaryotic species. DNA barcoding is currently being used for identification different groups such as birds, fish, ants, seaweed, diatoms, protozoa and plants (Chase et al., 2005; Smith et al., 2005; Hajibabaei et al., 2006; Evans et al., 2007). Research into fungal DNA barcoding was first conducted in 2003 by researchers at the University of Guelph in Canada. Significant progress was made in 2004 by Consortium for the Barcode of Life (CBOL). Then, more reliable identification tools were collected in DNA Barcode Reference Library (Nilsson et al., 2008). 


\section{DNA Barcoding in Fungi}

The total number of existing fungal species is unknown and the estimated maximum is 1.5 million species. So far, about 80000 to 120000 fungal species have been described (Hawksworth, 2004), an increase of 1.2 percent each year, which means that 1700 species are described each year. The use of DNA barcoding has become an important part of ecological research over the last 15-20 years, creating a new approach to biodiversity and the differences between different fungal groups (Hebert et al., 2003; Frézal and Leblois, 2008). DNA barcoding is a way to quickly, accurately and automatically identify species using a short, standard gene region as a way to identify differences between species. It is reliable and does not require high expertise which is used as a tool to accurately identify species in ecological studies and intraspecies diversity (Hebert et al., 2003; Frézal and Leblois, 2008; Das and Deb, 2015; Gosavi, 2016; Xu, 2016; Yahr et al., 2016; Chaudhary and Dahal, 2017). The COX1 gene was first used as a fungal barcode indicator for fungi (Taylor et al., 2000; Hebert et al., 2003). Today, however, the International Society of Mycology has replaced ITS-rDNA with a reference due to several problems including COX1 replication, the presence of multiple moving introns of different lengths, the presence of multiple copies of this gene, and the complete lack of clarity of COX1 in some taxons (Crous et al., 2009; Schoch et al., 2012; Das and Deb, 2015). Ribosomal RNA operon includes various parts that exist in the form of double replicates with multiple copies in the genome of living organisms. This area includes small subunit, large subunit, IGS, ITS and 5S regions. The structure of the ribosomal RNA operon is such that followed by small subunit (SSU), the ITS region situated which includes the ITS1 and ITS2 sequences, and we can observe the 5.8S gene between these two sections. After the ITS region, there is large subunit (LSU) and IGS region, which often consists of two sections, IGS1 and IGS2. In the distance between these two sections, in some groups, the $5 \mathrm{~S}$ region is located. Numerous primers have been designed to propagate this area in different fungal groups, including V9G / ITS4, ITS1 / ITS4, ITS5 / ITS4, and ITS1 / ITS4 (Crous et al., 2009; Schoch et al., 2012). ITS region with a large number of copies inside the genome, good variety between different fungal groups and other living organisms, conserved sequences for the design of primers and various genes with different evolutionary speeds is considered as the reference basis of barcoding studies. There are currently more than 100000 ITS sequences for fungi in the International Nucleotide Sequence Database (GenBank) as well as other databases, and in general, using of ITS as a complementary supplement in the identification of fungal species is common method (Crous et al., 2009; Schoch et al., 2012; Das and Deb, 2015; Mahmoud and Zaher, 2015; Gosavi, 2016; Xu, 2016; Badotti et al., 2017). However, the ITS region does not perform well in a small number of fungi, and it is not possible to identify some fungal groups at the species level based on ITS data (Crous et al., 2009). For example, in the fungal species with small spores such as Alternaria, Cercospora and some species of Fusarium, the ITS-rDNA region does not have sufficient potential to show diversity between different species, so, using of this region is only useful for identification at the genus or complex species but not suitable at species level (Crous et al., 2009). In a few cases, the sequence of the ITS region has considerable diversity within the populations of a fungal species, so, in this case the sequence of this region has the efficiency to separate species from each other. For example, in populations of Mycosphaerella musicola, there is a significant variation in the ITS sequence in different populations, while using of sequences of other protein-encoding genes support only one species of $M$. musicola within these populations. It is believed that after the recent species regeneration phenomena, due to the large number of ribosomal RNA operon, there is significant genetic diversity in the ITS region among different populations of new species which the sequences of this region will be homogeneous due to concerted evolution (Rooney and Ward, 2005). Ribosomal RNA small and large subunits (SSU and LSU) are used mainly to study deep order phylogeny due to their slow evolutionary rate. These regions have advantages mentioned for the ITS-rDNA area (having a large number of copies, the ability to design general primers, etc.). Today, mycologists are focusing on using LSU sequence data to identify and determine the boundaries of genera and higher levels taxons (Crous et al., 2009; Schoch et al., 2012). In cases where ITS data does not have the power to separate the phylogenetic position of some unknown or lesser-known species, it is recommended that the unknown isolate be determined first using LSU or SSU sequence data (Crous et al., 2009). Genomic studies and molecular information resulted in more consideration to other genes with high diversity. In general, target genes for fungi are diverse and include ITS rDNA, SSU rDNA, LSU 
rDNA, TEF-1a, Acitn, $\beta$-tubulin, RPB2, RPB1, Calmodulin and HistonH3 (Crous et al., 2009; Schoch et al., 2012). In the case of Fusarium species, for example, phylogeny based on the ribosomal DNA sequence of the ITS region could lead to unrealistic conclusions. In other hand, using of COX1 gene has several problems due to introns as well as multiple copies. Use of TEF-1a gene which is known as single-copy gene shows good polymorphism between closely related species in the genus Fusarium, compared to protein encoding genes such as $\beta$-tubulin, Calmodulin, and HistonH3. In the case of Cladosporium with more than 800 identified species, Acitn gene is used for identification species (Crous et al., 2009). Special tools have also been designed to identify several fungi. For example, species identification of Trichoderma based on the analysis of ITS and TEF-1 $\alpha$ sequences performed using TrichoKey or TrichoBLAST programs. Of course, the effectiveness of this method in identification of human pathogenic fungi is much higher (Druzhinina et al., 2005; Rooney and Ward, 2005).

\section{DNA Barcoding Steps}

The first step in DNA barcoding is to create a barcode reference sequence for different species of living organisms. References are placed in a global library with public accessibility, thus comparing and searching for unknown barcode sequences in the World Library, it is possible to quickly identify the unknown species. For this purpose, the consortium of barcode of living organisms cooperates with governmental and non-governmental organizations in different countries, and currently, this consortium is officially implementing joint DNA barcoding projects with 50 countries. In general, barcoding includes three main steps: 1) Collecting, identifying and maintaining reference samples in validate centers: Proper identification and maintenance of samples which used for preparing the reference barcode sequence is extremely important, because improper identification leads to an incorrect label on the reference barcode sequence, and it will not be possible to correctly identify the unknown species or isolates through DNA barcoding system. 2) DNA extraction from samples, multiplication of barcoding region and sequencing: Today, by using commercial kits, DNA extraction is performed with high speed. Replicating barcode sequences and sequencing using scientific methods is routine. 3) Data management: Finally, it is necessary to deposit the DNA barcode sequence as well as information on reference samples in public databases (Druzhinina et al., 2005; Kang et al., 2010; Begerow et al., 2010; Das and Deb, 2015; Gosavi, 2016).

\section{DNA Barcoding Problems and Challenges}

Today, a short barcode sequence is used to draw a phylogenetic tree, and although it reflects the accepted kinship relationship, some statistical criteria may cause internal problems. Also, DNA degradation in archival and biomaterial samples often prevents obtaining of fragments larger than 200 base pairs in the PCR method (Kang et al., 2010; Begerow et al., 2010). Another problem includes the lack of current methods for comprehensive analysis of environmental samples due to the high diversity of sequences which require separate set of primers for each major group. Lack of a general gene or a gene on all living domains is another problem that requires a lot of efforts (Kang et al., 2010; Begerow et al., 2010). On the other hand, there are many useful genetic sequences in the gene bank, all of them do not have the same validity. Old sequences that were generated and recorded manually are shorter and less accurate than recent sequences. Repeated gene propagation may be associated with errors caused by differences in the type of Taq polymerase or sequencing protocol. Also, the use of sequences obtained from a valid fungal culture is usually more valuable than miscellaneous sequences (Crous et al., 2009). In the case of the fungal species Pheoacromonium, a combination of characteristics such as morphological features, DNA information, and physiological characteristics can be used to identify the species (Mostert et al., 2006; Hawksworth, 2011).

\section{Important Notes on DNA Barcoding}

Researchers often look for homogeneous or homologous sequences in the analysis of phylogenetic relationships, and their similarity suggests that they are separated from a common ancestor. In the case of DNA barcoding, the orthologous genes, which are derived from a common 
ancestor as a result of the speciation process commonly used, but paralogous and xenologous genes are not used. In barcoding process, the accuracy of gene selection and the number of genes are very important. For example, the SSU and LSU sequences are used for high levels where the mutation rate is lower. There is also a need for analysis based on several genomes, which mainly uses protein encoding genes, but it is usually recommended to use a combination of coding and non-coding genes. In principle, gene regions should be selected in such a way that in addition to showing sufficient diversity, a genome-conserved region among different groups should also be considered. The obtained phylogenetic tree should be representative as species tree rather than gene tree. In the one gene based tree, if the studied gene was paralogous or xenologous, the results of phylogenetic concepts would not be corrected.

\section{Discussion}

Advances in new molecular methods, widespread use of these approaches in fungal taxonomy, efficiency of molecular data in solving the taxonomic problems of fungi and challenges in the rules of naming fungi in the last two years, the concept of one fungus = one name by some mycologists have suggested (Hawksworth, 2011; Taylor, 2011). They believe that considering 2 decades working on PCR techniques and also availability of living organism's nucleotide sequences in databases including fungal sequences, there is no need giving two different names as teleomorph and anamorph to fungi. So, determination fungal taxonomic position could be done only with nucleotide sequences and there is no need to have sexual phase. For this purpose, it is possible in near future that fungal nomenclature system will be separated from the International Code of Nomenclature for algae, fungi, and plants and give a mycocode to all of the fungi (Shenoy et al., 2007; Taylor, 2011). Problems and challenges in traditional methods based on morphology and the need for precision and speed in the taxonomy and correct diagnosis of living organisms have developed the importance of barcoding system in the identification of various human and plant pathogenic fungi. DNA barcoding is a highly efficient and accurate method for identification of species in all divisions using sequence data from one or more genes and could be applied in taxonomy, molecular phylogeny and population genetics (Hebert et al., 2003; Frézal and Leblois, 2008; Crous et al., 2009; 2009; Costa and Carvalho, 2010).

\section{Conclusion}

Considering new concept of "one fungus = one name" that has been proposed in recent years, it seems that DNA barcoding in fungi will become increasingly important. The results show the effectiveness of this approach in rapid and reliable identification of different fungal groups without any specialized knowledge of morphological characteristics. It should be noted, however, that DNA barcoding is still in its infancy, and there is a great need for extensive studies and research to achieve these goals.

\section{References}

Andersen, M. R., Salazaar, M. P., Schaap, P. J., van de Vondervoort, P. J. I., \& Culley, P. (2011). Comparative genomics of citric-acid-producing Aspergillus niger ATCC 1015 versus enzyme producing CBS 513.88. Genome Research, 21, 885-897.

Arver, B. A., Ward, T. J., Gale, L. R., Broz, K. L., Kistler, H. C., \& Aoki, T. (2011). Novel Fusarium head blight pathogens from Nepal and Louisiana revealed by multi locus genealogical concordance. Fungal Genetics and Biology, 48, 1077-1152.

Badali, H., Bonifaz, A., Barrón-Tapia, T., Vázquez-González, D., Estrada-Aguilar, L., \& Oliveira, N. M. (2010). Rhinocladiella aquaspersa proven agent of verrucous skin infection and a novel type of chromoblastomycosis. Medical Mycology, 48, 696-703.

Badali, H., Carvalho, V. O., Vicente, V., Attili-Angelis, D., Kwiatkowski, I. B., \& Gerrits Van Den Ende, A. H. (2009). Cladophialophora saturnica sp. nov. a new opportunistic species of chaetothyriales revealed using molecular data. Medical Mycology, 47, 51-62.

Badali, H., Gueidan, C., Najafzadeh, M. J., Bonifaz, A., Gerrits van den Ende, A. H. G., \& de Hoog, G. S. (2008). Biodiversity of the genus Cladophialophora. Studies in Mycology, 61, 175-191. 
Badali, H., Prenafeta-Boldu, F. X., Guarro, J., Klaassen, C. H., Meis, J. F., \& de Hoog, G. S. (2011). Cladophialophora psammophila, a novel species of Chaetothyriales with a potential use in the bioremediation of volatile aromatic hydrocarbons. Fungal Biology, 115, 1019-29.

Badotti, F., de Oliveira, F. S., Garcia, C. F., Vaz, A. B. M., Fonseca, P. L. C., Nahum, L. A., Oliveira, G., \& Góes-Neto, A. (2017). Effectiveness of ITS and sub-regions as DNA barcode markers for the identification of Basidiomycota (Fungi). BMC Microbiology, 17, 42-53.

Begerow, D., Nilsson, H., Unterseher, M., \& Maier, W. (2010). Current state and perspectives of fungal DNA barcoding and rapid identification procedures. Applied Microbiology and Biotechnology, 87, 99-108.

Chase, M. W., Salamin, N., Wilkinson, M., Dunwell, J. M., Kesanakurthi, R. P., \& Haidar, N. (2005). Land plants and DNA barcodes: short-term and long-term goals. Proceedings of the Royal Society of London, Series B, 360, 1889-1895.

Chaudhary, D. K., \& Dahal, R. H. (2017). DNA barcode for identification of microbial communities: a mini review. EC Microbiology, 7, 219-224.

Costa, F. O., \& Carvalho, G. R. (2010). New insights into molecular evolution: prospects from the Barcode of Life Initiative (BOLI). Theory on Biosciences, 129, 149-157.

Crous, P. W., Verkley, G. J. M., Groenewald, J. Z., \& Samson, R. A. (2009). Fungal Biodiversity. CBS Laboratory Manual Series 1. Centraal bureau voor Schimmel cultures: Utrecht. p. 269.

Das, S., \& Deb, B. (2015). DNA barcoding of fungi using Ribosomal ITS Marker for genetic diversity analysis: A Review. International Journal of Pure and Applied Bioscience, 3(3), 160-167.

Desjardins, C., Champion, M., Holder, J., Muszewsha, A., Goldberg, J., \& Baptista, A. J. (2011). Comparative genomic analysis of human fungal pathogens causing paracoccidioidomycosis. Plos Genetics, 7, e1002345.

Druzhinina, I. S., Kopchinskiy, A. G., Komoń, M., Bissett, J., Szakacs, G., \& Kubicek, C. P. (2005). An oligonucleotide barcode for species identification in Trichoderma and Hypocrea. Fungal Genetics and Biology, 42, 813-828.

Elahi, E., \& Ronaghi, M. (2004). Pyrosequencing: a tool for DNA sequencing analysis. Methods in Molecular Biology, 255, 211-219.

Evans, K. M., Wortley, A. H., \& Mann, D. G. (2007). An assessment of potential diatom "barcode” genes (cox1, rbcL, 18S and ITS rDNA) and their effectiveness in determining relationships in Sellaphora (Bacillariophyta). Protist, 158, 349-364.

Frézal, L., \& Leblois, R. (2008). Four years of DNA barcoding: Current advances and prospects. Infection Genetics and Evolution, 8, 727 -736.

Gadd, G. M. (2008). Geomycology: biogeochemical transformations of rocks, minerals, metals and radionuclides by fungi, bio-weathering and bio-remediation. Mycological Research, 111, 349.

Gosavi, M. C. (2016). Applications of DNA bar coding in molecular systematics of fungi: A review. International Journal of Life Sciences, A7, 111-115.

Hajibabaei, M., Janzen, D. H., Burns, J. M., Hallwachs, W., \& Hebert, P. D. N. (2006). DNA barcodes distinguish species of tropical Lepidoptera. Proceedings of the National Academy of Sciences USA, 103, 968-971.

Hawksworth, D. L. (2004). Fungal diversity and its implications for genetic resource collections. Studies in Mycology, 50, 9-18.

Hawksworth, D. L. (2011). A new dawn for the naming of fungi: impacts of decisions made in Melbourne in July 2011 on the future publication and regulation of fungal names. Myco Keys, 1, 7-20.

Hebert, P.D. N., Cywinska, A., Ball, S.L., \& deWaard, J. R. (2003). Biological identifications through DNA barcodes. Proceedings of the Royal Society of London, Series B, 270, 313-321.

Kang, S., Mansfield, M. A., Park, B., Geiser, D. M., \& Ivors, K. L. (2010). The promise and pitfalls of sequence-based identification of plant-pathogenic fungi and oomycetes. Phytopathology, 100, 732-737.

Mahmoud, A. G. Y., \& Zaher, E. H. F. (2015). Why nuclear ribosomal internal transcribed spacer (ITS) has been selected as the DNA barcode for fungi? Advancement in Genetic Engineering, 4, 119-120. 
Mostert, L., Groenewald, J. Z., Summerbell, R. C., Gams, W., \& Crous, P. W. (2006). Taxonomy and pathology of Togninia (diaporthales) and its Phaeoacremonium anamorphs. Studies in Mycology, 54, 1-115.

Nancy, L. W. Binnicker, M. J. (2009). Fungal molecular diagnostics. Clinics in Chest Medicine, 30, 391-408.

Nilsson, R. H., Kristiansson, E., Ryberg, M., \& Hallenberg, N. (2008). Intraspecific ITS variability in the kingdom fungi as expressed in the international sequence databases and its implications for molecular species identification. Evolution and Bioinformatics, 4, 193-201.

Raja, H. A., Miller, A. N., Pearce, C. J., \& Oberlies, N. H. (2017). Fungal identification using molecular tools: a primer for the natural products research community. Journal of Natural Products, 80, 756-770.

Rooney, A. P., \& Ward, T. J. (2005). Evolution of a large ribosomal RNA multigene family in filamentous fungi: Birth and death of a concerted evolution paradigm. Proceedings of the National Academy of Sciences USA, 102, 14, 5084-5089.

Schoch, C. L., Seifert, K. A., Huhndorf, S., Robert, V., Spouge, J. L., \& Levesque, C. A. (2012). Nuclear ribosomal internal transcribed spacer (ITS) region as a universal DNA barcode marker for Fungi. Proceedings of the National Academy of Sciences USA, 109, 6241-6246.

Shenoy, B. D., Jeewon, R., \& Hyde, K. D. (2007). Impact of DNA sequence-data on the taxonomy of anamorphic fungi. Fungal Diversity, 26, 1-54.

Smith, M. A., Fisher, B. L., \& Hebert, P. D. N. (2005). DNA barcoding for effective biodiversity assessment of a hyper diverse arthropod group: the ants of Madagascar. Proceedings of the Royal Society of London, Series B, 360, 1825-1834.

Taylor, J. W. (2006). Evolution of Human-Pathogenic Fungi: Phylogenies and Species. In J. Heitman, S. G. Filler, J. E. Edwards, \& A. P. Mitchell (Eds.), Molecular Principles of Fungal Pathogenesis (pp. 113-132). Washington DC, ASM Press.

Taylor, J. W. (2011). One fungus one name: DNA and fungal nomenclature twenty years after PCR. IMA Fungus, 2, 113-120.

Taylor, J. W., Jacobson, D. J., Kroken, S., Kasuga, T., Geiser, D. M., \& Hibbett, D. S. (2000). Phylogenetic species recognition and species concepts in fungi. Fungal Genetics and Biology, 31, 21-32.

Termorshuizen, A. J., \& Arnolds, E. J. M. (1997). On the nomenclature of the European species of the Armillaria mellea group. Mycotaxon, 30, 101-106.

Xu, J. (2016). Fungal DNA barcoding. Genome, 59, 913-932.

Xu, J. R., Peng, Y. L., Dickman, M. B., \& Sharon, A. (2006). The dawn of fungal pathogen genomics. Annual Review of Phytopathology, 44, 337-66.

Yahr, R., Schoch, C. L., \& Dentinger, B. T. M. (2016). Scaling up discovery of hidden diversity in fungi: impacts of barcoding approaches. Philosophical Transactions Royal Society B, 371, 20150336. 